\title{
IMPLEMENTASI APLIKASI AL-QUR'AN DIGITAL PADA SISWA KECANDUAN GADGET
}

\author{
Olan, Abdullah Idi, Ahmad Zainuri, Ari Sandi \\ Universitas Islam Negeri Raden Fatah Palembang, Indonesia \\ maliifakip@gmail.com, idi_abdullah@yahoo.com,ahmadzainuri_uin@radenfatah.ac.id \\ arisandi@radenfatah.ac.id
}

Received: 13-06-2019 Revised: 02-10-2019 Accepted: 26-10-2019

\begin{abstract}
The background of this research is (1) the majority of students have gadgets, (2) students spend more time playing gadgets than reading the Qur'an, (3) students have various social media applications and games but rarely have Al-Qur'an applications' an digital, (4) lack of student awareness in reading the Koran, (5) the need for guidance and motivation by teachers in reading the Qur'an with digital applications. The purpose of this study is to analyze the application of digital Al-Qur'an applications to gadget addicted students and to analyze how to overcome students addicted to gadgets using digital Al-Qur'an applications. Furthermore, this study uses qualitative research using a case study approach. The research subjects were 10 students who were addicted to mobile phones in the learning process at SMP Negeri 3 Tanjung Batu. Data collection uses observation, interviews, and documentation. Data analysis techniques using analysis refers to the concept of Miles and Huberman interactive models, namely: Data Collection, Data Reduction, Data Presentation and Drawing Conclusions. The results showed that the application of digital Al-Qur'an applications in the learning process of reading Al-Qur'an can belp direct students to use their cellphones on positive things, and want to change to prefer using their cellphones to read Al-Quran.
\end{abstract}

Keywords: Al-Qur'an, Application, Digital, Gadgets, Addictions

\section{Abstrak}

Latar belakang penelitian ini adalah (1) mayoritas siswa memiliki gadget, (2) siswa menghabiskan lebih banyak waktu bermain gadget daripada membaca Al-Qur'an, (3) siswa memiliki berbagai aplikasi dan game media sosial tetapi jarang memiliki aplikasi Al-Qur'an digital, (4) kurangnya kesadaran siswa dalam membaca Alquran, (5) perlunya bimbingan dan motivasi oleh guru dalam membaca Al-Qur'an dengan aplikasi digital. Adapun tujuan penelitian ini adalah untuk menganalisis penerapan aplikasi Al-Qur'an digital terhadap siswa kecanduan gadget dan untuk menganalisis bagaimana mengatasi siswa kecanduan gadget menggunakan aplikasi Al-Qur'an digital. Selanjutnya penelitian ini menggunakan penelitian kualitatif dengan menggunakan pendekatan studi kasus. Subjek penelitian adalah 10 siswa yang kecanduan ponsel dalam proses pembelajaran di SMP Negeri 3 Tanjung Batu. Pengumpulan data menggunakan observasi, wawancara, dan dokumentasi. Teknik analisis data menggunakan analisis mengacu pada konsep Miles and Huberman interactive model yaitu: Pengumpulan Data, Reduksi Data, Penyajian Data dan Penarikan Kesimpulan. Hasil penelitian menunjukkan bahwa penerapan aplikasi Al-Qur'an digital dalam proses pembelajaran membaca Al-Qur'an dapat membantu mengarahkan siswa untuk menggunakan ponsel mereka pada hal-hal positif, dan ingin berubah menjadi lebih suka menggunakan ponsel mereka untuk membaca Al-Qur'an.

Kata Kunci : Al-Qur'an, Aplikasi, Digital, Gadget, Kecanduan 


\section{PENDAHULUAN}

Al-Qur'an merupakan kitab suci umat Islam yang terdiri dari 114 surah 3666 ayat. Di dalamnya terdapat ajaran Islam yang terbagi pada lingkup syariah, ibadah, dan muamalah. AlQur'an merupakan salah satu mukjizat Rasulallah saw. Allah SW'T menurunkan Al-Qur'an kepada Nabi Muhammad SAW, demi membebaskan manusia dari berbagai kegelapan hidup menuju cahaya Ilahi, dan membimbing mereka ke jalan yang lurus. Bahkan, diantara kitabkitab suci yang lain hanya Al-Qur'an yang paling sempurna ${ }^{1}$. Kesempurnaan dan kemuliaan tercermin pada ajaran-ajaran yang terdapat di dalamnya selalu sesuai dengan perkembangan zaman, dalam arti bahwa semua yang berkaitan dengan kehidupan manusia selalu ada jawabannya dalam Al-Quran, oleh karena itu ia merupakan pedoman bagi umat Islam dalam bertindak dan berperilaku. Selain itu, ayat-ayat dalam Al-Quran, apabila dibaca maka dapat menentramkan jiwa manusia. Membaca Al-Qur'an baik mengerti artinya atau tidak telah termasuk dalam beribadah bagi umat Islam.

Pentingnya Al-Qur'an bagi kehidupan manusia, menunjukkan bahwa ia tidak hanya sekedar dibaca namun juga dipahami, dan diamalkan. Oleh karena itu, sangat diperlukan pengajaran Al-Qur'an pada anak-anak sejak usia dini. Nilai-nilai ajaran Islam dalam Al-Qur'an dapat diketahui dan diamalkan isinya apabila umat Islam membacanya. Pengajaran membaca Al-Qur'an menjadi tanggungjawab bagi setiap muslim, terutama dimulai dari orangtuanya. Sedangkan, di sekolah pengajaran membaca Al-Qur'an dilakukan melalui proses pembelajaran pada mata pelajaran Pendidikan Agama Islam (PAI).

Pada kurikulum 2013, pengajaran Al-Qur'an termasuk pada Kompetensi Dasar Membaca Al-Quran. Siswa dituntut agar mampu membaca Al-Qur'an dengan baik dan benar. Guru dibimbing membaca Al-Qur'an melalui guru mata pelajaran PAI pada proses belajar mengajar di kelas. Kemampuan siswa membaca Al-Qur'an yang baik dan benar memerlukan tahapan-tahapan tertentu, hal ini sesuai yang dikatakan bahwa kemampuan membaca AlQur'an dapat dimiliki melalui beberapa tahapan, yaitu tahap kemampuan melafalkan hurufhuruf dengan baik dan benar, sesuai dengan makhroj dan sifatnya ${ }^{2}$. Tahap kemampuan membaca ayat-ayat Al-Qur'an sesuai dengan hukum-hukum tajwid dan kemampuan membaca Al-Qur'an dengan lancar dan tetap memperhatikan kaidah-kaidah ilmu tajwid, sehingga mampu melaksanakan anjuran rasulullah yaitu membaca 30 juz dalam sebulan. Jalaluddin menyatakan bahwa kemampuan membaca Al-Qur'an dapat diraih melalui tiga tahapan, yaitu mengenal karakter haruf, bunyi huruf, dan membacanya.

Penguasaan siswa pada materi membaca ayat Al-Qur'an sangat penting dalam pembelajaran PAI, tidak hanya penting dalam memenuhi target dan tujuan pembelajaran, tetapi lebih dari itu sangat penting bagi siswa sebagai seorang muslim agar dapat melaksanakan ajaran agamanya, mencintai Al-Quran, membaca dan memahami, serta mengamalkan ajarannya. Secara pribadi, sebagai umat Islam kemampuan membaca ayat Al-Qur'an menunjukkan penguasaannya dalam mempelajari Al-Quran.

Seiring dengan perkembangan zaman, Al-Qur'an dibuat dalam bentuk digital melalui sebuah aplikasi berupa Al-Qur'an digital. Al-Qur'an digital merupakan produk perubahan cara berpikir yang semakin memudahkan urusan manusia, di tengah teknologi di dalam segala

${ }^{1}$ Maktabah Wahbah, Pengantar Studi Ilmu Al-Qur'an (Jakarta: Pustaka Al-Kausar, 2005), 3.

2 Jalaluddin, Metode Telunjuk dalam Al-Qur'an (Jakarta: Grasindo, 2012), 19. 
bidang yang mengalami kemajuan, baik dari segi ragam, kualitas dan kuantitasnya. Kemajuannya di masa datang tentunya akan sangat erat kaitannya dengan perkembangan teknologi informasi dan komunikasi, sehingga Al-Qur'an digital banyak diminati oleh masyarakat ${ }^{3}$. Jenis Al-Qur'an digital bermacam-macam, ada yang berbasis aplikasi komputer (software), web dan aplikasi ponsel. Software dan apliaksi Al-Qur'an digital ini pada umumnya didistribusikan secara gratis. Fitur yang terdapat dari aplikasi digital beraneka ragam pula, mulai dari mencari ayat, mencari kata dan derivasinya, terjemahan ke dalam berbagai bahasa, asbabub nuzul sekaligus ada kutipan penjelasan dari berbagai macam tafsir, belum lagi dalam prakteknya ternyata software-software ini cukup mudah untuk digunakan dan mudah pula disunting (copy, paste, ganti jenis, ukuran dan style huruf) ${ }^{4}$.

Permasalahan yang sering terjadi di dunia pendidikan saat ini adalah kemampuan membaca Al-Qur'an siswa di sekolah umumnya masih rendah. Hal ini terjadi karena minimnya siswa yang membiasakan diri membaca Al-Quran. Siswa lebih banyak yang tertarik pada gadget daripada membaca Al-Quran. Oleh karena itu, salah satu upaya yang dapat dilakukan dalam meningkatkan kemampuan membaca Al-Qur'an pada siswa adalah melalui penggunaan aplikasi Al-Qur'an Digital, seperti yang terdapat dalam gadget. Gadget merupakan alat untuk berkomunikasi antar individu dan penting pula dalam mencari informasi. Seiring dari penggunaan gadget sebagai alat berkomunikasi, handpone mengalami perkembangan yang sangat dasyatnya sehingga melalui gadget seseorang dapat melakukan banyak hal secara online melalui aplikasi dalam gadget.

Pada perkembangannya gadget semakin lebih baik setiap tahunnya. Selalu ada merek dan tipe baru yang dijualbelikan pada pembeli. gadget yang tersedia memiliki kecanggihan karena memuat berbagai aplikasi online yang dibutuhkan oleh masayarakat. Melalui tampilannya yang menarik dan dengan kecepatan yang tinggi untuk mencari informasi dan untuk berkomunikasi maka semakin menarik bagi seseorang untuk memiliki dan menggunakan gadget. Seseorang dapat menggunakan gadget untuk berbelanja berbagai kebutuhan hidup, kebutuhan sekolah, dan lain-lain. Melalui gadget juga seseorang dapat lebih cepat dalam berkomunikasi dengan orang lain dari jarak jauh. Melalui gadget juga seseorang dapat memesan aplikasi transportasi online yang siap mengantarkan kemanapun tujuan yang terjangkau. Melalui gadget seseorang dapat bermain game dengan berbagai variasi permainan yang telah dikemas secara menarik.

Penggunaan gadget yang salah dapat merusak generasi, terutama anak-anak atau remaja usia sekolah. Kesalahan dalam menggunakan gadget misalnya dilakukan dengan intensitas menggunakan gadget di luar kebiasaan normal, yakni memiliki ketergantungan yang tinggi. Seperti yang di jelaskan dalam penelitian yang dilakukan oleh Tonna dkk, menunjukkan bahwa, salah satu dampak dari penggunaan gadget terlihat pada pergeseran nilai kearifan lokal, seperti, permainan tradisional yang dulu dimainkan oleh anak-anak sekarang telah beralih pada permainan game online yang dinilai lebih menarik dan menyenangkan ${ }^{5}$. Faiz Noormiyanto

3 Syarif Hidayat, “Al-Qur'an Digital (Ragam, Permasalahan dan Masa Depan)," Mukaddimab: Jurnal Studi Islam 1, no. 1 (2018): 1-40. https://doi.org/10.14421/mjsi.11.1333.

${ }^{4}$ Hidayat. 1-20.

${ }^{5}$ Tonna Balya, Sri Pratiwi, dan Reza Prabudi, "LITERASI MEDIA DIGITAL PADA PENGGUNAAN GADGET (Studi Deskriptif Penggunaan Gadget Pada Siswa SMK Broadcasting Bina 
menjelaskan dalam penelitinya, jika penggunaan gadget pada anak secara berlebihan akan berdampak pada interaksi sosial anak, oleh sebab itu, orangtua dan guru harus mengatur dalam penggunaan gadget pada anak. ${ }^{6}$ Kamsih Astuti dan Sri Widayani, dalam penelitianya juga menjelaskan semakin tinggi persepsi pola asuh demokratis maka kecanduan gadget cenderung semakin rendah, dan sebaliknya semakin rendah persepsi pola asuh demokratis maka kecanduan gadget cenderung semakin tinggi. ${ }^{7}$ Lalu kemudian hasil temuan yang di teliti oleh Bayu Abdurrahman, Yulia Febrianita dan Ainil Fitri menjelaskan bahwa, hasil temuannya menyatakan sebanyak 53 orang (53\%) dalam katagori cukup baik tentang gambaran pengetahuan phubbing akibat kecanduan gadget pada generasi Z. ${ }^{8}$ Oleh sebab itu, Bayu Abdurrahman, Yulia Febrianita dan Ainil Fitri selaku peneliti, mengharapkan SMA Negeri 9 Kota Pekanbaru Riau dapat mengadakan penyuluhan tentang phubbing akibat kecanduan gadget.

Lain halnya penelitian Ana Diniati, Jarkawi, Farial. Berdasarkan hasil penelitian dalam layanan bimbingan kelompok dalam mengurangi kecaduaan anak yang menggunakan gadget,adalah sebagai berikut: 1. Layanan bimbingan kelompok dalam mengurangi kecanduan anak yang menggunakan gadget di SMK Negeri 1 paringin, yaitu Guru Bimbingan Konseling memberikan layanan bimbingan bimbingan kelompok tentang gadget. 2. Proses pelaksanaan bimbingan kelompok tentang informasi gadget di SMK Negeri 1 Paringin dilaksanakan melalui ketentuan program pemerintah materi yang disampaikan, materi yang akan disampaikan oleh pihak sekolah, dan kemudian melakukan pendekatan kepada siswa yang akan dilakukan pemberian layanan bimbingan konseling. 3. Pentingnya keterlibatan sekolah dalam mengurangi kecanduaan anak yang menggunakan gadget, meliputi berbagai cara di antaranya adalah: Regulasi, peraturan dan kedisiplinan. ${ }^{\text {? }}$

Maya Ferdiana Rozalia, Hasil penelitian pada variabel prestasi belajar secara umum siswa kelas V SDN SeGugus VIII Kecamatan Blimbing Kota Malang tergolong pada kategori cukup. Hasil analisis uji korelasi menunjukkan hubungan negatif yang sangat rendah dan tidak signifikan. Hipotesis menyatakan ada hubungan negatif yang tidak signifikan antara intensitas pemanfaatan gadget dengan prestasi belajar siswa kelas V SDN Se-gugus VIII Kecamatan Blimbing Kota Malang diterima. Intensitas pemanfaatan gadget tidak berpengaruh pada

Creative Medan Yang Berdampak Pada Pergeseran Nilai Kearifan Lokal)," JURNAL SIMBOLIKA: Research and Learning in Communication Study 4, no. 2 (2018): 173-87, https://doi.org/10.31289/simbollika.v4i2.1898.

${ }^{6}$ Faiz Noormiyanto, "Pengaruh Intensitas Anak Mengakses Gadget Dan Tingkat Kontrol Orangtua Anak Terhadap Interaksi Sosial Anak SD Kelas Tinggi Di SD 1 Pasuruhan Kidul Kudus Jawa Tengah,” Elementary School 5, no. 1 (2018): 138-48, https://doi.org/10.31316/elementary\%20schoo.v5i1.607.

${ }^{7}$ Sri Widayani dan Kamsih Astuti, "Pembentukan Karakter Melalui Pola Asuh Demokratis Untuk Mencegah Kecanduan Gadget Remaja Di Era Revolusi Industri 4.0,” Psycho Idea 18, no. 1 (2020): 74-81, https://doi.org/10.30595/psychoidea.v18i1.6234.

${ }^{8}$ Ainil Fitri, Yulia Febrianita, dan Bayu Abdurrahman, "GAMBARAN PENGETAHUAN TENTANG PHUBBING AKIBAT KECANDUAN GADGET PADA GENERASI Z DI SMA NEGERI 9 KOTA PEKANBARU PROVINSI RIAU," Jurnal Keperawatan Abdurrab 3, no. 2 (2020): 46-52, https://doi.org/10.36341/jka.v3i2.1120.

9 Ana Diniati dan Jarkawi Jarkawi, "Layanan Bimbingan Kelompok Dalam Mengurangi Kecanduan Anak Yang Menggunakan Gadget Di Smk Negeri 1 Paringin," Jurnal Mahasiswa BK An-Nur: Berbeda, Bermakna, Mulia 3, no. 3 (2018): 1-4, http://dx.doi.org/10.31602/jmbkan.v3i3.1229. 
prestasi belajar siswa. Namun jika dilihat dari tanda negatif pada $r_{\text {hitung }}$, jika semakin tinggi intensitas pemanfaatan gadget maka prestasi siswa dapat menurun. ${ }^{10}$

Akan tetapi, lain halnya dengan kajian yang di teliti oleh Kharisma Bismi Alrasheed dan Melani Aprianti, dalam Penelitiannya bahwa terdapat hubungan negatif antara kecanduan gadget dengan kecerdasan emosi pada siswa SMP di Kecamatan Setiabudi Jakarta Selatan. Artinya, semakin tinggi kecanduan gadget maka akan memiliki tingkat kecerdasan emosi yang rendah dan sebaliknya jika kecanduan gadget rendah maka akan memiliki tingkat kecerdasan emosi yang tinggi. ${ }^{11}$

Lalu kemudian hasil penelitian Kharisma Bismi Alrasheed dan Melani Aprianti di perkuat lagi dari hasil penelitian yang di teliti oleh Dian Kurniawati, Berdasarkan hasil penelitian dan pembahasan di atas bahwa penggunaan gadget dapat berpengaruh terhadap prestasi siswa. Dapat kita lihat pengaruhnya dengan nilai rata-rata sebesar 56\%. Siswa yang sering menggunakan gadget akan mengalami kecanduan, siswa kecanduan pada aplikasi yang ada pada gadget dari game, jejaring sosial, internet dan aplikasi lainnya yang serings iswa gunakan. Dalam hal ini siswa akan mengalami penurunan tingkat prestasinya. Akan tetapi jika gadget dapat dimanfaatkan oleh siswa dengan baik maka dapat digunakan sebagai sarana dalam belajarnya untuk menunjang tingkat prestasinya. Oleh karena itu diperlukan peran orang tua dan guru untuk mengawasi dan membatasi waktu yang tepat pada penggunaan gadget. Orang tua dan guru dapat memberikan gadget kepada siswa sesuai kebutuhan siswa misalnya saat siswa mengalami kesulitan saat belajar atau kurang paham terhadap materi yang dipelajari maka siswa dapat memanfaatkan gadget untuk mencari informasi yang mengedukasi. ${ }^{12}$

Tidak jauh berbeda dari penelitian Tonna dkk di atas, permasalahan berkaitan dengan penggunaan gadget juga terjadi di SMP Negeri 3 Tanjung Batu. Hasil observasi awal menunjukkan adanya permasalahan yaitu kemampuan membaca Al-Quran, mayoritas siswa mengenal aplikasi digital, mayoritas siswa memiliki gadget dan sering menggunakannya dalam kehidupan sehari-hari. Kenyataannya, banyak siswa yang memiliki gadget lebih peduli dengan gadgetnya dari pada teman dan saudaranya, dan banyak siswa yang memiliki gadget, berlangganan internet bahkan rela menyisihkan uang sakunya untuk membeli koata internet, namun tidak memanfaatkan hanphone dan aplikasi Al-Qur’an digital melalui gadgetnya dalam membaca dan memahami Al-Qur'an.

Penelitian ini dilakukan di Sekolah Menengah Pertama Negeri 3 Tanjung Batu. Sekolah ini dipilih dijadikan subjek penelitian karena sekolah memiliki visi dan misi menciptakan lingkungan yang Islami, dimana siswa diarahkan agar mampu membaca Al-Quran. Sekolah telah mengadakan program ekstrakurikuler seni membaca Al-Qur'an dalam mewujudkan misi dan visi tersebut, akan tetapi walaupun telah ada programnya namun belum berjalan sesuai

${ }^{10}$ Maya Ferdiana Rozalia, "Hubungan intensitas pemanfaatan gadget dengan prestasi belajar siswa kelas V sekolah dasar," Jurnal Pemikiran dan Pengembangan Sekolah Dasar (JP2SD) 5, no. 2 (2017): 722-31, https://doi.org/10.22219/jp2sd.v5i2.4821.

11 Kharisma Bismi Alrasheed dan Melani Aprianti, "Kecanduan Gadget Dan Kaitannya Dengan Kecerdasan Emosi Remaja (Sebuah Studi Pada Siswa Smp Di Kecamatan Setiabudi Jakarta Selatan)," Jurnal Sains Psikologi 7, no. 2 (2018): 136-42, http://dx.doi.org/10.17977/um023v7i22018p136.

12 Dian Kurniawati, "Pengaruh Penggunaan Gadget terhadap Prestasi Siswa," Edukatif: Jurnal Ilmu Pendidikan 2, no. 1 (2020): 78-84, https://doi.org/10.31004/edukatif.v2i1.78. 
dengan harapan dalam arti belum mampu membudayakan membaca Al-Qur'an pada siswanya. Oleh karena itu, kepala sekolah dan guru Pendidikan Agama Islam berupaya untuk memberdayakan siswa mampu membaca Al-Qur'an melalui pembelajaran agama di sekolah. Permasalahannya adalah siswa lebih terbiasa bermain gadget daripada membaca Al-Qur'an (Kepala Sekolah \& Guru PAI, 2019). Akan tetapi, hal yang mustahil untuk menghentikan siswa dengan gadget secara total, karena kebutuhan dalam berkomunikasi melalui gadget dibutuhkan di zaman modern ini. Guna mengatasinya maka, peneliti memberikan solusi untuk mengarahkan siswa menggunakan gadgetnya untuk hal-hal yang positif seperti membaca AlQur'an melalui aplikasi Al-Qur'an Digital.

Berdasarkan latar belakang di atas, maka peneliti tertarik untuk mengkaji lebih lanjut mngenai probelem siswa kecanduan gadget, kemudian masalah dalam penelitian ini yaitu bagaimana implementasi penggunaan aplikasi Al-Qur'an digital terhadap siswa kecanduan gadget? dan bagaimana mengatasi siswa kecanduan gadget menggunakan aplikasi Al-Qur'an digital?

\section{Kajian Literatur}

\section{Pengertian Aplikasi Al-Quran Digital}

Digital berasal dari kata digitus, dalam bahasa Yunani berarti jari jemari. Apabila kita hitung jari jemari orang dewasa, maka berjumlah sepuluh (10). Nilai sepuluh tersebut terdiri dari 2 radix, yaitu 1 dan 0 , oleh karena itu digital merupakan penggambaran suatu keadaan bilangan yang terdiri dari angka 0 dan 1 atau off dan on (bilangan biner). Semua sistem komputer menggunakan sistem digital sebagai basis datanya. ${ }^{13}$

Literasi digital adalah ketertarikan, sikap dan kemampuan individu dalam menggunakan teknologi digital (Situs/website, E-mail, Forum di Internet, Internet, Blog, Wiki, Aplikasi pesan/gadget, The RSS, MUDs, Media Sosial) dan alat komunikasi untuk mengakses, mengelolah, mengintegrasikan, menganalisis dan mengevaluasi informasi, $\mathrm{m}$ embangun pengetahuan baru, membuat dan berkomunikasi dengan orang lain agar dapat berpartisipasi secara efektif dalam masyarakat. ${ }^{14}$

Salah satu apllikasi digital adalah Al-quran. Aplikasi ini dibuat secara khusus bagi seorang muslim yang tidak memiliki banyak waktu untuk membaca Al-Quran, sehingga dengan bantuan aplikasi digital setiap Muslim masih tetap dapat membaca Al-quran dimanapun dan kapanpun ia berada.

Al-Qur'an digital merupakan sebuah aplikasi yang memuat Al-Quran dalam sebuah gadget, baik di dalam gadget maupun di dalam CD. Kemajuan Al-Quran digital di masa datang sangat erat kaitannya dengan perkembangan teknologi informasi dan komunikasi. Secara spesifik dapat disebutkan bahwa teknologi komputerlah yang tetap akan menjadi tumpuan kemajuan Al-Quran Digital di masa yang akan datang. Kemajuan teknologi komputer akan saling beriringan satu sama lain antara kemajuan perangkat keras dan perangkat lunak sebagai "nyawa" dari perangkat keras tersebut. Berbagai model dan format baru Al-Quran Digital tentunya akan bermunculan seiring dengan bermunculannya model dan jenis perangkat keras komputer dan piranti lunak yang lainnya. ${ }^{15}$

Format digital Al-Quran kini tersedia dalam berbagai versi: ada yang berupa gambar dalam aplikasi Al-Quran digital, ada yang berupa font yang dapat diinstalasikan ke dalam

13 Juliana Kurniawati dan Siti Baroroh, "Literasi Media Digital Mahasiswa Universitas Muhammadiyah Bengkulu," Jurnal Komunikator 8, no. 2 (2016): 51-66.

14 Rulli Nasrullah, "Teori dan Riset Media Siber (Cybermedia): Edisi Pertama," Jakarta: Kencana Media Group, 2014.

${ }^{15}$ Hidayat, "Al-Qur'an Digital (Ragam, Permasalahan dan Masa Depan).” 
sistem operasi komputer, maupun teks digital biasa yang bisa diakses dan diolah dengan aplikasi pengolah kata. Berbagai bentuk teks digital yang sudah ada dapat dimanfaatkan dalam beberapa penggunaan yang terbatas, seperti aplikasi Al-Quran digital untuk bacaan, dan lain sebagainya. ${ }^{16}$ Al-Qur'an digital sebagai sebuah aplikasi berbasis Islam berkembang untuk mengimbangi kemajuan zaman, sehingga umat Islam memperoleh kemudahan dari aplikasi tersebut terutama untuk beribadah atau mempelajari ajaran-ajaran Islam.

Berdasarkan uraian di atas, diketahui bahwa Al-Quran Digital adalah suatu aplikasi yang berisi ayat suci Al-Quran sebanyak 30 juz, beserta terjemahannya dalam bentuk digital atau aplikasi baik online maupun manual. Aplikasi ini dihubungkan pada android, komputer, ataupun CD. Format Al-Quran digital ada dua, yaitu ada yang berupa gambar dalam aplikasi Al-Quran digital, ada yang berupa font yang dapat diinstalasikan ke dalam sistem operasi komputer, maupun teks digital biasa yang bisa diakses dan diolah dengan aplikasi pengolah kata.

\section{Pengertian Gadget}

Gadget merupakan sebuah media yang berkembang sejak pertengahan tahun 1990-an, sejak membawa teknologi Instragram/IG (Generasi pertama) yaitu menggunakan teknologi AMPS (Advance Mobile Phone System). ${ }^{17}$ Sebagai sebuah media dalam berkomunikasi, gadget merupakan salah satu kebutuhan bagi individu atau sekelompok individu dalam rangka menunjang aktivitasnya sehari-hari.

Gadget termasuk ke dalam media digital atau media baru. Media digital merupakan suatu perangkat yang membutuhkan teknologi tinggi, orang-orang yang bekerja di dunia pendidikan cenderung memiliki kegemaran untuk selalu melakukan suatu inovasi di dalam lingkungan pembelajarannya. Ketika lembaga penyelenggara pendidikan dan pembelajaran sudah dituntut mengimplementasikan pada media digital, hal yang baik adalah lembaga penyelenggara pendidikan dan pembelajaran tidak perlu susah dalam memotivasi siswa untuk menggunakannya, karena secara tidak langsung dengan sendirinya siswa lebih menyenangi pembelajaran menggunakan media digital. ${ }^{18}$

Gadget memiliki banyak manfaat, terutama dalam efektif dan efisiensi waktu penggunanya. Ia merupakan sebuah alat yang membantu kelancaran aktivitas yang dilakukan. Ibrahim dan Akhmad menyatakan terdapat empat kegunaan gadget yaitu:

a. Media komunikasi interpersonal

b. Media permainan interaktif seperti email

c. Media pencarian informasi seperti mesin pencarian di Net

d. Media partisipatoris seperti ruang chet di $\mathrm{Net}^{19}$

Dari keempat kategori utama penggunaan gadget, diketahui bahwa gadget merupakan sebuah media komunikasi antar personal, media informasi dan partisipasi seseorang terhadap oranglain. Memiliki sebuah gadget dapat memudahkan seseorang dalam berkomunikasi dengan oranglain, dan juga memudahkan dalam mencari informasi yang dibutuhkan secara online.

Akan tetapi, gadget sebagai alat berkomunikasi dapat menjadi masalah apabila seseorang memiliki ketergantung yang tidak normal terhadap gadget. Kecanduan gadget menyebabkan seseorang dapat melupakan hal yang lebih penting dalam hidupnya sehingga merugikan dirinya sendiri.

\footnotetext{
${ }^{16}$ Hidayat.

${ }^{17}$ H Kasiyanto Kasemin, Agresi Perkembangan Teknologi Informasi (Prenada Media, 2016).

18 Balya, Pratiwi, dan Prabudi, "LITERASI MEDIA DIGITAL PADA PENGGUNAAN GADGET (Studi Deskriptif Penggunaan Gadget Pada Siswa SMK Broadcasting Bina Creative Medan Yang Berdampak Pada Pergeseran Nilai Kearifan Lokal)."

${ }^{19}$ Balya, Pratiwi, dan Prabudi.
} 
Kecanduan gadget adalah suatu ketergantungan seseorang terhadap gadget, dimana waktumya lebih banyak dihabiskan dengan bermain gadget, dan tidak dapat terlepas dari gadgetnya. Kecanduan ini merupakan kebiasaan buruk yang harus dihindari oleh siapapun, terutama bagi anak muda sebagai generasi penerus bangsa.

\section{METODE PENELITIAN}

Jenis penelitian yang adalah penelitian lapangan (file research). Metode yang digunakan adalah metode penelitian kualitatif. Menurut Nana Syaodih Sukmadinata penelitian kualitatif adalah suatu penelitian yang ditujukan untuk menganalisis secara mendalam dan mendeskripsikan suatu fenomena, peristiwa, aktivitas sosial, sikap, pemikiran, kepercayaan, persepsi orang secara individu maupun kelompok. ${ }^{20}$ Sebab dipilihnya penelitian kualitatif pokok utama yang akan diungkapkan adalah siswa kecanduan gadget yang merupakan fonomena telah berkembang saat ini. ${ }^{21}$ Karenanya dalam mengeksplorasi data diperlukan pertanyaan-pertanyaan yang terbuka, ${ }^{22}$ dan mengharuskan peneliti untuk terlibat langsung dalam objek penelitian, kemudian pendekatan dalam penelitian ini menggunakan pendekatan studi kasus khususnya pada anak kecanduan gadget.

Subjek Penelitian ini adalah siswa yang mengalami kecanduan gadget di SMP Negeri 3 Tanjung Batu Kabupaten Ogan Ilir tahun 2018-2019, berjumlah 10 orang, sedangkan objek penelitian ini adalah implementasi aplikasi Al-Qur'an digital pada siswa kecanduan gadget di SMP Negeri 3 Tanjung Batu Kabupaten Ogan Ilir. selanjutnya sumber data dalam penelitian ini meliputi sumber data primer dan sumber data sekunder. 1) Sumber data primer adalah sumber data yang dikumpulkan langsung dari guru dan siswa di SMP Negeri 3 Tanjung Batu. 2) Sumber data sekunder adalah data yang mendukung berupa bahan-bahan yang sudah jadi, kepustakaan, buku, artikel jurnal yang ada di SMP Negeri 3 Tanjung Batu.

Teknik pengumpulan data penelitian ini menggunakan teknik, Observasi, Wawancara dan Dokumentasi. Setelah data terkumpul, selanjutnya dipilah sesuai dengan tema yang ada, kemudian diproses sehingga menjadi tipologi satuan data. Tahap ini akan membentuk satuan informasi tersendiri. Pada tahap selanjutnya adalah menentukan dan memberikan makna (definisi), dan terakhir dengan penafsiran data (interpretasi). Jadi, teknis analisis data yang digunakan dalam penelitian ini mengacu pada konsep Miles and Huberman interactive model, adapun model interaktif yaitu: Pengumpulan Data, Reduksi Data, Penyajian Data dan Penarikan Kesimpulan. ${ }^{23}$

Analisis komponen-komponen model interaktif data yaitu: Pertama, reduksi data yaitu data yang diperoleh ditulis dan diuraikan secara terperinci, selanjutnya dirangkum dan dipilah sesuai fokus dan temanya. Data yang direduksi menggambarkan lebih tajam hasil pengamatan, dan juga mempermudah untuk mencari kembali data yang telah diperoleh. Kedua, display data yaitu dengan membuat berbagai macam pengklasifikasian dari keseluruhan data sehingga menjadi mudah disimpulkan. Klasifikasi dapat berupa berdasarkan tema, tabel, grafik atau pemetaan sehingga dapat disimpulkan secara tepat. Ketiga, kesimpulan dan verifikasi yaitu

${ }^{20}$ Nana Syaodih Sukmadinata, Metode penelitian pendidikan (Bandung: Remaja Rosdakarya, 2005), 60.

${ }^{21}$ John W Creswell, Research design: pendekatan metode kualitatif, kuantitatif, dan campuran (Yogyakarta: Pustaka Pelajar, 2016), 24.

22 Creswell, 24.

23 Matthew B Miles dan A Michael Huberman, Analisis Data Kualitatif. Terjemahan Tjetjep Rohendi Robidi (Jakarta: Penerbit Universitas Indonesia, 1992), 18. 
kesimpulan yang tentatif dari seluruh data yang telah direduksi dan didisplay. Akan tetapi kesimpulan yang bersifat tentatif tersebut akan diverifikasi melalui data-data yang diperoleh kemudian sehingga menjadi semakin terjamin dan mencapai kebenaran. Jadi, verifikasi yang dilakukan adalah untuk menguji kesimpulan-kesimpulan yang bersifat sementara yang lahir dalam proses pencarian data-data tersebut.

\section{HASIL PENELITIAN}

\section{Implementasi penggunaan aplikasi Al-Qur'an digital terhadap siswa kecanduan gadget}

Penelitian ini bertujuan untuk mengetahui penerapan aplikasi Al-Qur'an Digital melalui gadget pada proses pembelajaran membaca Al-Quran. Aplikasi yang dipilih untuk digunakan dalam pembelajaran adalah aplikasi jenis Qur'an versi 1.04. Aplikasi ini dipilih karena memiliki kelebihan yaitu file aplikasi cukup kecil dan tidak memakan banyak memori penyimpanan dalam ponsel, sehingga memudahkan bagi siswa yang memiliki gadget android jenis apapun. Selain itu, aplikasi ponsel jenis Qur'an versi 1.04 ini ringan dalam penggunaan, tidak dibutuhkan waktu jeda dalam membuka setiap halaman surat yang terdiri dari banyak ayat sehingga memudahkan dalam proses pembelajaran dan tidak menggunakan waktu yang banyak terutama pada proses pembelajaran membaca Al-Qur'an yang terbatas hanya dua jam pelajaran. Kelemahan dari aplikasi ini seperti fitur yang terbatas, tidak menjadi persoalan karena aplikasi ini hanya digunakan untuk membaca Al-Quran.

Penerapan aplikasi Al-Qur'an digital pada proses pembelajaran membaca Al-Qur'an dilakukan selama tiga kali pertemuan. Pertemuan pertama dilakukan kegiatan membaca AlQur'an secara bersama-sama dan diikuti dengan membaca dan memahami kandungan ayat AlQur'an yang dibaca. Pertemuan kedua dilakukan kegiatan membaca Al-Qur'an dengan aplikasi Al-Qur'an digital per kelompok, dan pada pertemuan ketiga dilakukan kegiatan membaca AlQur'an per individu.

Pertemuan ke-1

Penerapan aplikasi Al-Qur'an digital pertemuan pertama berlangsung pada hari Selasa 21 Januari 2020. Pada proses pembelajaran membaca Al-Qur'an pertemuan pertama ini dilakukan dengan langkah-langkah sebagai berikut:

Pertama, Semua siswa diarahkan untuk menginstal aplikasi Al-Qur'an digital jenis Qur'an versi 1.04 pada gadgetnya masing-masing. Kedua. Setelah semua siswa memiliki aplikasi tersebut, maka bersama-sama siswa peneliti membuka aplikasi untuk membaca AlQur'an berikut dengan terjemahannya. Diawali dengan mengucap membaca taawuz, basmallah kemudian dilanjutkan dengan membaca Al-Qur'an secara bersama-sama. Ayat Al-Qur'an yang dipelajari adalah Surah Al-Maidah ayat 1 sampai dengan 5. Pemilihan ayat ini bertujuan agar siswa tidak hanya mengerti bacaan ayat Al-Quran, namun juga diajak bersama-sama memahami kandungan dari ayatnya. Peneliti bermaksud untuk menanamkan nilai-nilai Al-Qur'an dalam ayat tersebut agar berangsur-angsur tidak kecanduan gadget pada proses pembelajaran melainkan dapat focus belajar karena hal tersebut berguna bagi dirinya. Peneliti menjelaskan bahwa dalam kehidupan ini harus berpegang teguh pada ajaran Islam dalam Al-Qur'an dan hadits. Tidak diperkenankan untuk menggunakan waktu luang pada hal-hal yang buruk seperti membuka situs fornografi atau ketergantungan bermain game online, apalagi dalam jam pelajaran yang sedang berlangsung.

Ketiga, setelah semua siswa membaca Al-Qur'an bersama-sama maka kegiatan pembelajaran diakhiri dengan berdoa bersama yang dipimpin oleh satu orang siswa. Pada 
observasi terhadap kegiatan penerapan aplikasi Al-Qur'an digital pada proses pembelajaran membaca Al-Qur'an pertemuan ke-1 ini, semua siswa membaca Al-Qur'an dengan baik, dan mendengarkan dengan penuh perhatian dan dapat menyimak makna dari terjemahannya. Hasil pengamatan ini didukung dengan pendapat mereka pada wawancara, yaitu:

"Kami merasa senang dapat memiliki aplikasi ini. Sebelumnya belum pernah membaca Al-Qur'an dalam gadget, lebih seringnya menggunakan gadget untuk bermain game, kalau menonton fornografi tidak pernah" 24

Setelah meminta pendapat siswa, maka peneliti bermaksud melakukan kegiatan menerapkan aplikasi tersebut pada pertemuan ke-2. Peneliti meminta agar mereka menggunakan aplikasi ini setiap hari, namun pada pertemuan ke-2 mendatang akan dilakukan kegiatan membaca Al-Qur'an secara berkelompok.

\section{Pertemuan ke-2}

Kegiatan menerapkan aplikasi Al-Qur'an digital pada proses pembelajaran membaca Al-Qur'an pertemuan ke-2 berlangsung pada hari Selasa 28 Januari 2020. Pada pertemuan ini, peneliti mengajak siswa untuk kembali membaca Al-Qur'an yang ada dalam gadget, namun dengan cara yang berbeda.

Langkah awal dalam pertemuan ini adalah membentuk siswa menjadi tiga kelompok, masing-masing dua kelompok berjumlah 3 orang, dan 1 kelompok berjumlah 4 orang. Materi yang dipelajari adalah surah Al-Maidah ayat 6 sampai dengan 8. Mula-mula membaca Al-Qur'an pada setiap kelompok secara bersama-sama sebanyak 2 kali. Kemudian masing-masing 1 ayat untuk satu kelompok untuk didemonstrasikan di depan kelas, setelah selesai kemudian diberi waktu pada setiap kelompok untuk bergantian membaca ketiga ayat secara bergiliran pada anggota kelompoknya. Pada kegiatan ini, siswa diarahkan untuk mandiri tanpa dibimbing oleh peneliti.

Di akhir waktu, 15 menit sebelum berakhir maka kembali peneliti menngajak siswa membaca terjemahannya dan menjelaskan maknanya. Setelah selesai, kemudian kegiatan diakhiri dengan berdoa bersama-sama untuk mengakhiri pertemuan.

\section{Pertemuan ke-3}

Pada pertemuan ke-3 berlangsung hari Selasa 4 Februari 2020. Pada pertemuan ini, peneliti mengarahkan siswa untuk membaca ayat Al-Qur'an dengan menggunakan aplikasi yang ada secara bergiliran per individu. Nampak semua siswa membaca Al-Qur'an dengan baik. Pada kegiatan ini, ada tiga orang siswa yang bertanya tentang tajwid yang dibacanya dan meminta peneliti untuk membetulkan. Setelah semua siswa telah mendapat giliran membaca Al-Quran, kemudian peneliti menunjuk dua orang siswa secara bergantian untuk membaca terjemahannya, dan meminta dua orang lagi untuk menjelaskan maknanya. Materi yang dipelajari adalah surah Al-Maidah ayat 9 sampai 18. Masing-masing individu, membaca ayat sesuai dengan gillirannya.

Setelah selesai pembelajaran maka peneli mengajak siswa untuk bersama-sama membaca Al-Qur'an pada ayat 8 sampai dengan ayat 10. Kemudian kegiatan diakhiri dengan berdoa bersama yang dipimpin oleh salah satu siswa.

Selama kegiatan berlangsung dari pertemuan ke-1 sampai pertemuan ke-3. Peneliti melakukan pengamatan dan wawancara. Pengamatan dilakukan oleh observer pendamping

\footnotetext{
${ }^{24}$ SGT MGA dan JLS, Wawancara, 1 Januari 2020.
} 
yaitu guru mata pelajaran PAI sedangkan wawancara peneliti lakukan sendiri. Dari hasil observasi terhadap kegiatan siswa yang mengalami kecanduan gadget pada proses pembelajaran membaca Al-Qur'an diperoleh data sebagai berikut:

Tabel 1

Data Hasil Observasi terhadap Aktivitas Penerapan Aplikasi Al-Qur'an Digital pada siswa kecanduan gadget

\begin{tabular}{ccccc}
\hline \multirow{2}{*}{ No } & \multirow{2}{*}{ Kode Siswa } & \multicolumn{3}{c}{ Keaktifan dalam Membaca Al-Quran } \\
\cline { 2 - 5 } & & Pertemuan ke-1 & Pertemuan ke-2 & Pertemuan ke-3 \\
\hline 1 & SGT & Aktif & Aktif & Aktif \\
\hline 2 & MGA & Aktif & Aktif & Aktif \\
\hline 3 & JLS & Aktif & Aktif & Aktif \\
\hline 4 & SSH & Tidak aktif & Aktif & Aktif \\
\hline 5 & ATP & Tidak aktif & Aktif & Aktif \\
\hline 6 & ALK & Tidak aktif & Tidak aktif & Aktif \\
\hline 7 & DRC & Tidak aktif & Aktif & Aktif \\
\hline 8 & MAT & Aktif & Aktif & Aktif \\
\hline 9 & DAS & Tidak aktif & Tidak Aktif & Aktif \\
\hline 10 & KIM & Aktif & Aktif & Aktif \\
\hline
\end{tabular}

Sumber: Dokumentasi hasil observasi guru PAI, 2020

Dari observasi tersebut diketahui bahwa selama tiga kali pertemuan dalam penerapan aplikasi Al-Qur'an digital yang telah dilakukan, pertemuan pertama ada 5 orang siswa yang aktif dan 5 orang siswa yang tidak aktif. Pada pertemuan ke-2, ada 8 orang siswa yang aktif dan 2 orang siswa yang tidak aktif, pada pertemuan ke-3 semua siswa aktif. Berdasarkan hasil wawancara pada siswa, diketahui pendapat mereka tentang penerapan aplikasi Al-Qur'an digital yang telah dilakukan yaitu:

"Saya secara individu merasa lebih termotivasi untuk membaca Al-Qur'an dan menggunakan gadget untuk kegiatan yang positif. Kalau saya, merasa senang dan bersemangat belajar terutama memaca Al-Qur'an karena kegiatannmya menyenangkan dan kami merasa lebih dekat dengan ajaran agama Islam. Selama ini, daripada bengong, lebih baik bermain game apalagi selalu penasaran dengan kemampuan kami bermain game dan membuat kami selalu ingin mencoba dan tidak mau berhenti. Dan terutama karena bosan belajar dikelas". ${ }^{25}$

\section{Mengatasi Kecanduan gadget dengan Penggunaan Aplikasi Al-Qur'an Digital}

Penelitian ini membahas tentang mengatasi kecanduan gadget dengan penggunaan aplikasi Al-Qur'an Digital.Aplikasi tersebut diterapkan pada siswa yang kecanduan gadget pada kegiatan pembelajaran juga sulit terlepas dari gadgetnya. Mengatasi kecanduan gadget dengan aplikasi Al-Qur'an digital pada penelitian ini dilakukan dengan langkah-langkah sebagai berikut:

Memberikan bimbingan kelompok dengan cara mengarahkan siswa untuk menceritakan awal ia kecanduan gadget

Kecanduan gadget merupakan suatu perbuatan yang menunjukkan adanya gejala ketergantungan antara individu dengan gadgetnya, sehingga ia tidak dapat terlepas dari benda

${ }^{25}$ MAT KIM SGT, Wawancara, 1 Januari 2020. 
tersebut. Akibat dari ketergantungan itu melalaikan dirinya dari aktivitas lain yang lebih penting dalam hidupnya. Mengatasi kecanduan gadgettidak dapat dilakukan secara spontan namun berangsur-angsur, misalnya dengan mengalihkan siswa pada penggunaan gadget untuk sesuatu yang bermanfaat, misalnya mempelajari atau membaca Al-Quran.Pada penelitian ini, selain mengatasi kecanduan gadget penggunaan aplikasi Al-Qur'an digital bertujuan agar siswa yang sebelumnya tidak dapat berkosentrasi sewaktu belajar karena ketergantungan gadget dapat segera mengatasi masalahnya.Oleh karena itu, sebelum menggunakan aplikasi Al-Qur'an digital melalui gadget pada siswa secara berkelompok terlebih dahulu peneliti menanyakan persepsi siswa tentang gadgetitu sendiri.

Berdasarkan hasil wawancara, observasi, dan dokumentasidiketahui siswa sepakat bahwa gadget adalah alat untuk berkomunikasi.Berikut jawaban siswa selengkapnya.

"Alat untuk berkomunikasi. ${ }^{26}$ Alat untuk berkomunikasi jarak jauh, ${ }^{27}$ gadget itu adalah teknologi yang berguna untuk menelpon dan untuk chating, memberi pesan kepada teman-teman, dan saudara atau keluarga". ${ }^{28}$

Dari hasil wawancara tersebut diketahui bahwa persepsi siswa tentang definisi gadget secara umum sama yaitu sebuah benda yang berguna sebagai alat untuk berkomunikasi dengan orang lain, untuk menelpon dan mengirim pesan dari jarak jauh. Akan tetapi, siswa tidak menggunakannya secara tepat, dalam arti berkomunikasi dengan batas yang wajar hanya sebatas untuk berkomunikasi.Siswa mengakui keberadaan gadget bagi dirinya sangat penting.Semua siswa menjawab bahwa gadget sangat penting untuk berkomunikasi dengan orang lain. Keterkaitan akan gadget tidak dapat dihindarinya. ${ }^{29}$

Siswa merasakan bahwa kepentingan gadget sangat penting dan tidak dapat dipisahkan dalam kehidupannya sehari-hari. Persepsi siswa itu sendiri berkaitan dengan definisi kencanduan gadget adalah sebagai berikut:

"Kecanduan gadget adalah keterkaitan dengan gadget. ${ }^{30}$ Terikatan dengan gadget dan sulit melepaskannya. ${ }^{31}$ Rasa memiliki gadget dan tidak dapat terlepas dari gadget". ${ }^{32}$

Dari hasil wawancara tersebut di atas, diketahui bahwa persepsi siswa terhadap kecanduan gadget adalah adanya keterkaitan, keterikatan, sulit melepaskan, dan tidak dapat terlepas dari gadget yang dimilikinya.Hal ini menunjukkan adanya sebuah perbuatan yang intens dengan gadget, dalam aktivitasnya dimanapun dan kapanpun berada selalu melihat gadgetnya.

Guna mengatasi kecanduan gadget, peneliti berupaya untuk mengetahui terlebih dahulu penyebab siswa bisa kecanduan gadget.Dari hasil wawancara diketahui bahwa:

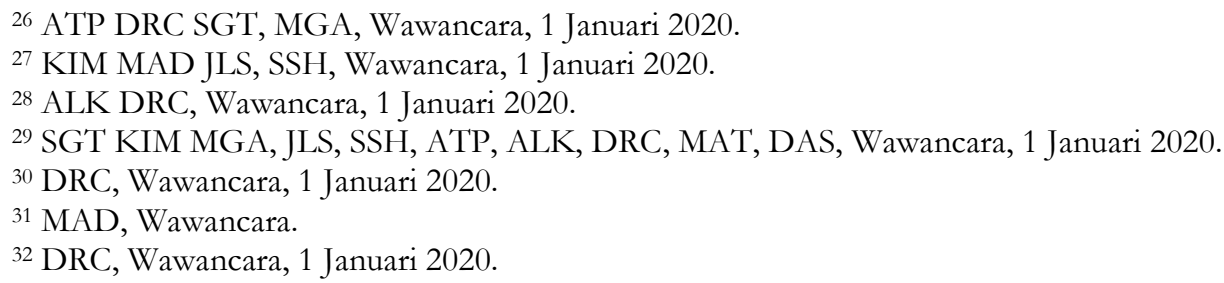


"Mulanya saya bermain game, kemudian saya coba bermain dan pada akhirnya selalu ada rasa penasaran ingin memenangkan permainan itu. ${ }^{33}$ Saya awalnya kecanduan chating dengan teman-teman, kemudian saling bercerita, lalu menemukan permainan bersama-sama teman-teman bertanding game. ${ }^{34}$ Awalnya saya itu tidak mau makan sayur, kemudian ibu saya memberi game agar saya mau makan, begitu terus sampai saya $\mathrm{SD}$, dan saya bermain game terus sampai sekarang. ${ }^{35}$ Saya bermain Game karena merasa senang, dan selalu ingin main pak" ${ }^{\prime 36}$

Berdasarkan uraian tersebut diketahui bahwa terdapat berbagai penyebab siswa kecanduan gadget, yaitu karena coba-coba, merasakan senang karena bermain game, rasa penasaran yang tinggi terhadap game, bentuk kasih sayang ibu yang salah dalam memilih alternative bagi anak untuk makan sayur. Apapun penyebabnya, siswa kecanduan gadget tidak dapat terlepas dari gadgetnya karena telah merasakan kesenangan bermain gadget, dalam hal ini persepsi siswa yang kecanduan gadget adalah merasa selalu senang ketika bermain game yang disukainya sehingga tidak dapat melepaskan game pada gadgetnya tersebut.

\section{Memberi dorongan untuk mengatasi kecanduan gadget}

Setelah mengetahui persepsi siswa tentang gadget, maka sebagai langkah kedua adalah memberi dorongan pada siswa untuk mengatasi ketergantungannya dengan gadget.Dalam hal ini, peneliti memberikan pemahaman siswa akan dampak negatif penggunaan gadget yang berlebihan. Siswa diarahkan untuk menemukan sendiri dampak tersebut agar muncul kesadaran dari dalam dirinya secara individu dan diharapkan ia dapat berubah karena dorongan dari dalam dirinya sendiri. Hasil wawancara menunjukkan bahwa:

"Saya tidak mengetahui dampak negatifnya pak, mungkin kecanduan ini dampaknya. Mungkin lupa waktu pak. Jadi malas belajar pak. Selalu jadi ketergantungan pak. Kalau saya selama tergantung dengan game jadi sering kena marah orangtua karena boros pulsa pak"37

Dari hasil wawancara tersebut diketahui bahwa siswa pada umumnya semua menyadari dampak negatif dari ketergantungan gadget, hanya satu orang yang tidak mengetahuinya secara yakin sehingga ia tetap menggunakan gadget dalam intensitas yang tinggi. Akan tetapi mereka telah mengetahui gadget yang digunakan secara berlebihan dapat berpengaruh negatif bagi dirinya seperti menimbulkan kecanduan, menyebabkan lupa waktu, malas belajar, kena marah orangtua, dan menyebabkan gaya hidup boros. Berkaitan dengan jawaban siswa ini, peneliti kemudian menanyakan pada siswa apakah dampak negatif menggunakan gadget pada saat belajar di kelas, semua siswa menjawab tidak dapat berkosentrasi.

"Dampaknya saya kalau belajar tidak kosentrasi pak, Iya, ada dampaknya pak, tidak dapat ikut pelajaran dengan maksimal.Kami tidak kosentrasi. Hasil belajar kami

\footnotetext{
${ }^{33}$ DRC, Wawancara, 1 Januari 2020.

${ }^{34}$ MAD, Wawancara.

35 MAD.

${ }^{36}$ DRC, Wawancara, 1 Januari 2020.

${ }^{37}$ DRC.
} 
cenderung turun pak, sebenarnya kami mampu belajar pak, namun keinginan untuk melihat gadget lebih tinggi daripada belajar". ${ }^{38}$

Dari hasil wawancara tersebut diketahui bahwa persepsi siswa tentang dampak negatif kecanduan gadget dalam belajar di kelas adalah tidak dapat belajar dengan baik karena tidak kosentrasi dan tidak dapat menolak keinginan untuk membuka gadgetnya.Siswa secara individu memahami dirinya tidak dapat mengendalikan diri dalam membuka gadget swaktu belajar di kelas, dan minat siswa untuk terlepas dari ketergantungan gadget juga ada namun mereka tidak mengetahui caranya.

"Iya, pak. Kami semua mau berubah, tidak tergantung lagi dengan gadget. Namun sulit rasanya pak, mau menghentikan keinginan membuka gadget, terkadang tangan tanpa sengaja sudah membuka gadget. Saya mau pak kosentrasi belajar, tetapi ketika gadget disita bu guru kami beli lagi gadget lain. Tidak tahu caranya mau berhenti pak". ${ }^{39}$

Berdasarkan hasil observasi menunjukkan siswa tidak dapat mengendalikan diri untuk bermain game pada gadgetnya, bahkaniamembuka hp sembunyi-sembunyi, untuk sekedar membuka media social, mengetahui info pembaruan temannya. Hal ini sebagai mana data observasi tentang frekuensi siswa menggunakan gadgetnya di kelas:

Tabel 4.1

Frekuensi Siswa Menggunakan gadget

\begin{tabular}{cccccc}
\hline No & $\begin{array}{c}\text { Kode } \\
\text { Siswa }\end{array}$ & $\begin{array}{c}\text { Frekuensi Di } \\
\text { Rumah }\end{array}$ & Aktivitas & $\begin{array}{c}\text { Frekuensi Di } \\
\text { sekolah }\end{array}$ & Aktivitas \\
\hline 1 & SGT & 4 jam & Game & 3 kali & Wa, fb \\
\hline 2 & MGA & 5 jam & Game & 4 kali & Wa, fb \\
\hline 3 & JLS & 4 jam & Game & 3 kali & Game \\
\hline 4 & SSH & $3-4$ jam & Game & 2 kali & Wa, fb \\
\hline 5 & ATP & 6 jam & Wa, game & 4 kali & Game, wa \\
\hline 6 & ALK & 5 jam & Game & 4 kali & Wa, fb \\
\hline 7 & DRC & 6 jam & Fb, game & 3 kali & Wa, fb \\
\hline 8 & MAT & 5 jam & Game & 3 kali & Wa, fb \\
\hline 9 & DAS & 5 jam & Game & 2 kali & Wa \\
\hline 10 & KIM & 4 jam & Game & 4 kali & Wa, fb \\
\hline
\end{tabular}

Sumber: Dokumentasi hasil observasi pada Siswa, Januari 2020

Dari tabel di atas, diketahui bahwa siswa yang kecanduan gadget memilliki daya tahan yang berjam-jam untuk bermain gadget, paling sedikit dua jam, dan paling lama enam jam per hari. Bahkan ketika berada di sekolah pun siswa masih sempat bermain gadget dengan

38 KIM, Wawancara, 1 Januari 2020.

${ }^{39}$ KIM, Wawancara, 1 Januari 2020. 
membuka media social watshap dan facebook, namun ada pula yang bermain game, frekuensinya paling sedikit 2 kali paling banyak 4 kali membuka hp pada saat belajar.

Terhadap aktivitas siswa bermain gadget ini, proses bimbingan berlangsung per kelompok.Fasilitas bimbingan yang digunakan adalah kartu bimbingan, ketersediaan adanya kerjasama guru PAI dan guru BK, minat siswa untuk berhenti menggunakan gadget untuk hal yang buruk.Metode bimbingan yang digunakan adalah diskusi dan pembiasaan, dan sanksi.Pada kegiatan bimbingan yang berlangsung kemudian digunakanpendekatan kelompok.

Siswa yang kecanduan gadget dibagi dalam tiga kelompok, yaitu kelompok 1 (tiga orang), kelompok 2 (tiga orang), dan kelompok 3 (empat orang). Proses berlangsung dimana peneliti, dibantu oleh guru PAI dan guru BK memberikan bimbingan pada masing-masing kelompok, kemudian memberikan pemahaman dampak negative menggunakan gadget yang berlebihan, serta dampak moral apabila tidak dapat mengendalikan diri terhadap keinginan yang menggebu. Siswa diarahkan untuk mengerti dampak tersebut melalui contoh yang kongkrit dari pengalaman masing-masing individu pada saat belajar.Setelah itu, siswa secara kelompok juga diberi arahan untuk menggunakan gadget pada hal-hal yang baik yang memberi manfaat untuk kehidupan akhirat, contohnya membaca Al-Quran.Di akhir pertemuan, siswa diminta komitmennya, apabila selama 3 kali pertemuan membuat laporan secara jujur tentang aktivitasnya bermain gadget di rumah, sebagai tindak lanjut hasil laporannya diketahui oleh orangtuanya.

\section{Membimbing secara individu agar memahami fungsi gadget}

Setelah membimbing siswa per kelompok dilakukan, maka langkah selanjutnya adalah membimbing siswa per individu agar mampu memahami fungsi gadget. Bimbingan dilakukan dengan terlebih dahulu menjelaskan fungsi gadget pada siswa, dalam hal ini siswa ditunjuk satu per satu fungsi gadget yang diketahuinya, kemudian dibahas bersama-sama.Setelah menjelaskan fungsi gadget, langkah selanjutnya adalah mengarahkan siswa untuk menunjukkan kelebihan gadget. Dalam hal ini, metode yang digunakan dengan cara mendemonstrasikan kelebihan gadget pada siswa untuk digunakan pada hal-hal yang positif.

Berdasarkan hasil observasi fasilitas bimbingan individu adalah gadget masing-masing siswa, ruang BK. Proses bimbingan berlangsung dengan menggunakan metode bimbingan individu, dan pendekatan individu. Proses pembelajaran diterapkan dengan metode demonstrasi. Pada saat proses bimbingan berlangsung, semua siswa mengikuti dengan baik, aktif, dan bersemangat. Hal ini karena siswa telah terbiasa menggunakan gadget, akan tetapi pada proses bimbingan ini siswa secara individu di arahkan untuk menggunakan gadget pada hal-hal yang positif seperti untuk kegiatan pembelajaran.Sebagai hasil akhir yang dikehendaki pada langkah ketiga ini adalah, siswa secara individu berminat tinggi untuk menggunakan gadget pada aktivitas yang bermanfaat dalam kehidupannya sehari-hari, misalnya pada kegiatan pembelajaran membaca Al-Quran.

\section{Mengarahkan siswa untuk menggunakan aplikasi al-Qur'an digital}

Langkah keempat ini adalah langkah terakhir yang dilakukan dalam kegiatan bimbingan kelompok dan individu pada siswa yang kecanduan gadget untuk kegiatan yang merugikannya. Sebagai tindak lanjut dari bimbingan individu adalah pengenalan aplikasi AlQur'an digital. Siswa diarahkan untuk memiliki aplikasi Al-Qur'an digital untuk mengurangi kegiatannya bermain game, sehingga melalui aplikasi ini siswa diberi penugasan untuk 
membaca Al-Qur'an setiap hari, baik di rumah maupun di sekolah. Dalam hal ini, ketika berada di sekolah melalui kelompoknya siswa dilatih membaca Al-Qur'an melalui aplikasi AlQur'an digital yang telah dimilikinya, kemudian sebagai tindakan untuk menguranginya bermain game di rumah maka siswa diberi tugas untuk latihan membaca Al-Qur'an di rumah dan dipantau oleh guru PAI dan peneliti.

Pengenalan aplikasi Al-Qur'an digital, tugas yang diberikan pada siswa, juga diikuti dengan menjelaskan kelebihan Al-Qur'an digital danfungsinya. Untuk menguatkan semangat siswa maka dijelaskan pula keutamaan orang membaca Al-Qur'an pada siswa, sehingga ia merasa yakin dan mau membiasakan diri membaca Al-Qur'an walaupun melalui aplikasi dalam gadgetnya.

Berdasarkan hasil obervasi diketahui bahwa aktivitas siswa pada saat proses pengenalan aplikasi Al-Qur'an digital berlangsung, 80\% siswa mendengarkan dengan baik, bertanya, dan bersemangat dalam mengikuti kegiatan pembelajaran yang berlangsung, sedangkan 20\% lainnya siswa tidak aktif namun mengikuti sampai selesai. Dari hasil wawancara menunjukkan bahwa tanggapan siswa tentang aplikasi Al-Qur'an digital adalah sebagai berikut:

"Saya sangat senang mengetahui aplikasi ini, dan saya akan gunakan dengan baik. Melalui aplikasi ini, saya tidak repot membawa Al-Qur'an dan saya telah latihan dengan rajin. Saya senang memiliki aplikasi ini, jadi tidak malas membaca Al-Quran. Saya senang dan meras terbantu membaca Al-Quran.Saya senang, walaupun pada awalnya merasa malas karena suntuk, sekarang setelah latihan membaca setiap hari, saya menyukainya.Saya senang, jadinya melupakan game. Saya tidak kecanduan game lagi karena waktunya sudah dialihkan latihan membaca Al-Quran. Saya dan ibu saya merasa senang karena waktu saya bermanfaat. Alhamdulillah saya dapat mengurangi bermain game secara berangsur-angsur". ${ }^{40}$

Dari jawaban tersebut diketahui bahwa siswa telah menyukai aplikasi Al-Qur'an digital karena mudah dan terbiasa menggunakannya. Siswa mengakui pada awalnya membosankan bagi beberapa orang, kemudian seiring waktu dengan keterpaksaan akhirnya menjadi terbiasa dan menyukai latihan membaca Al-Qur'an dengan aplikasi ini. Siswa merasa bersyukur karena, waktunya dalam bermain game secara berangsur-angsur telah bergeser digantikan dengan latihan membaca Al-Quran.

\section{PEMBAHASAN}

\section{Mengatasi Kecanduan Handphne}

Mengatasi kecanduan gadget pada siswa yang bermasalah dengan benda tersebut dilakukan menggunakan metode bimbingan kelompok dan bimbingan individu. Metode ini dilakukan secara bertahap dengan pendekatan kelompok, pendekatan individu, serta metode yang bervariasi sesuai dengan topic yang dibahas dalam kegiatan bimbingan yang dilakukan.Kegiatan ini diawali dengan mengetahui penyebab siswa kecanduan gadget, kemudian memberikan bimbingan sesuai penyebabnya itu. Siswa diarahkan untuk menemukan sendiri penyebab ia kecanduan gadget, kemudian ditanya, aktivitas apa yang dilakukan serta aplikasi apa yang membuatnya kecanduan. Siswa kemudian dibimbingan dengan mengarahkan ia

${ }^{40}$ KIM, Wawancara, 1 Januari 2020. 
menemukan fungsi handphone, kelebihannya, dan kerugiannya apabila disalah gunakan. Hal ini bertujuan agar siswa menyadari dari dalam dirinya kesalahan dari perilakunya selama ini sehingga menggunakan waktu yang berjam-jam untuk bermain game, dan sosial media.

Hasil wawancara menunjukkan bahwa siswa kecanduan gadget karena mencoba aplikasi game yang ada di hpnya baik diberitahu teman, maupun orangtuanya. Siswa terbiasa menggunakan handphone untuk bermain game sejak kecil, terutama ketika ia menangis meminta sesuatu atau tidak mau makan. Siswa setiap hari menggunakan gadgetnya untuk bermain game 2 sampai 6 jam ketika berada di rumah, dan 2 sampai 4 kali ketika berada di kelas dengan membuka media sosial. Cara siswa menggunakan handphone di sekolah adalah dengan cara sembunyi-sembunyi, ketika guru menjelaskan pelajaran.

Melalui bimbingan individu, siswa dibimbingan untuk menggunakan handphonenya pada kegiatan yang positif misalnya membaca Al-Qur'an, sehingga terbiasa setiap hari menggunakan aplikasi tersebut dan telah menggeser kebiasaannya bermain game secara berangsur-angsur. Hasil observasi menunjukkan bahwa siswa optimis dan bersemangat dalam menggunakan handphonenya pada kegiatan yang positif.

\section{Menerapkan Aplikasi Al-Quran Digital pada Proses Pembelajaran}

Dari penerapan aplikasi Al-Qur'an digital yang telah dilakukan selama tiga kali pertemuan pada 10 orang siswa yang kecanduan handphone pada proses pembelajaran membaca Al-quran diketahui bahwa siswa yang kecanduan gadget dalam proses pembelajaran mengaku bahwa mereka merasa senang memiliki aplikasi ini dan terutama dapat berangsurangsur memahami waktu luang dan waktu belajar untuk kegiatan yang positif terutama membaca Al-Qur'an. Selama ini, sebagian siswa mengaku bahwa tidak tahu cara menggunakan waktu luang sehingga lebih memilih bermain game pada gadgetnya terutama ketika mengetahui ada tantangan untuk selalu menang dalam game yang dimainkan, sampai pada akhirnya mereka ketergantuang dan tidak dapat terbebas dari pikiran untuk bermain game online termasuk pada proses pembelajaran membaca Al-Qur'an yang sedang berlangsung di sekolah.

Pada hasil observasi dan wawancara yang telah dilakukan diketahui hampir semua siswa menyukai aplikasi ini.Dan mereka secara bertahap dapat aktif, mula-mula hanya sebagian pada pertemuan pertama, kemudian sebagian besar aktif pada pertemuan ke- 2 dan semua aktif pada pertemuan ke-3. Hasil wawancara menunjukkan mereka melalui pendekatan secara personal dan kelompok dari tiga kali pertemuan serta dengan variasi membaca ayat dan membaca kandungan ayatnya mengaku bahwa aplikasi alquran digital, terutama kegiatan tersebut dapat mendekatkan mereka pada ajaran Islam dan mau berubah untuk lebih memilih menggunakan handphonenya untuk membaca Al-Qur'an.

\section{Aplikasi Al-Quran digital dapat mengatasi kecanduan gadget dan dapat} meningkatkan kemampuan membaca Al-Qur'an siswa di SMP Negeri 3 Tanjung Batu

Aplikasi Al-Quran digital pada penelitian ini digunakan untuk dua tujuan, yaitu membantu mengatasi siswa kecanduan gadget e pada saat pembelajaran berlangsung, dan juga untuk meningkatkan kemampuan membaca Al-Qur'an pada siswa di SMP Negeri 3 Tanjung Batu.Kegiatan pembelajaran yang telah berlangsung selama 3 kali pertemuan praktik membaca Al-Quran di sekolah menggunakan Aplikasi Al-Qur'an digital, dan 3 kali penugasan di rumah 
dimana siswa dibiasakan untuk memmbaca Al-Qur'an setiap hari secara individu, untuk mengganti kebiasaannya bermain game.

Setelah siswa mempraktikkan membaca Al-Qur'an menggunakan aplikasi Al-Qur'an digital pada proses pembelajaran yang sedang berlangsung, aktivitas siswa membaik setiap pertemuan, baik aktivitas mendengarkan, memperhatikan, bertanya, maupun aktivitas siswa mempraktikkan membaca Al-Qur'an. Kemampuan siswa membaca Al-Qur'an melalui aplikasi ini, juga cenderung meningkat.Hal ini berarti melalui aplikasi Al-Qur'an digital kemampuan siswa membaca Al-Qur'an dapat ditingkatkan dengan optimal.Hal ini terjadi karena, siswa pada saat pembelajaran berlangsung dapat mengikuti dengan baik, kemudian diikuti dengan pendekatan pembiasaan dengan metode demonstrasi, siswa dapat mengikuti kegaitan yang berlangsung secara individu dan kelompok.

\section{KESIMPULAN}

Berdasarkan uraian yang telah dikemukakan pada hasil penelitian dan pembahasan dapat disimpulkan sebagai berikut:

Pertama, mengatasi perbuatan kecanduan gadget pada penelitian ini dilakukan dengan metode bimbingan kelompok dan bimbingan individual, dengan pendekatan diskusi (wawancara pribadi), demosntrasi, dan pembiasaan membaca Al-Quran dengan tujuan untuk mengalihkan aktivitas siswa menggunakan gadget untuk bermain game dan media sosial di sekolah dan di rumah dengan kebiasaan membaca Al-Qur'an melalui aplikasi Al-Qur'an digital. Siswa dibimbing dengan mengarahkannya untuk membaca Al-Qur'an secara sadar agar kebiasaan buruk bermain game secara berjam-jam menjadi berkurang dengan menggantinya membaca Al-Qur'an.

Kedua, penerapan aplikasi Al-Qur'an digital dalam proses pembelajaran membaca AlQur'an dalam penelitian ini dilakukan melalui tiga tahapan yaitu dengan memperkenalkan aplikasi dan manfaatnya, memperkenalkan materi ayat Al-Qur'an dan keguanaan membacanya, serta dilakukan dengan modifikasi metode belajar dari kelompok ke individu dan disertai pengkajian nilai-nilai yang terkandung di dalamnya. Aplikasi ini dapat diterapkan dengan cara pembiasaan membaca Al-Qur'an dan dibimbing oleh guru PAI. Rekomendasi yang peneliti sumbangkan dalam penelitian ini adalah aplikasi Al-Qur'an digital dalam handhpne dapat membantu mengarahkan siswa untuk menggunakan handhponenya pada hal-hal yang positif, terutama untuk mendekatkan diri pada Allah, swt.

Ketiga, aplikasi Al-Qur'an digital dapat membantu mengatasi kecanduan gadget pada siswa dan mampu meningkatkan kemampuannya membaca Al-Qur'an. Aplikasi ini dapat diterapkan pada proses pembelajaran yang berlangsung karena siswa dapat mengikuti dengan optimal. Oleh karena itu, guru mata pelajaran PAI di SMP Negeri 3 Tanjung Batu dapat menerapkan aplikasi ini dalam membaca Al-Qur'an. 


\section{REFERENSI}

Alrasheed, Kharisma Bismi, dan Melani Aprianti. "KECANDUAN GADGET DAN KAITANNYA DENGAN KECERDASAN EMOSI REMAJA (SEBUAH STUDI PADA SISWA SMP DI KECAMATAN SETIABUDI JAKARTA SELATAN)." Jurnal Sains Psikologi 7, no. 2 (2018): 136-42. http://dx.doi.org/10.17977/um023v7i22018p136.

Balya, Tonna, Sri Pratiwi, dan Reza Prabudi. "LITERASI MEDIA DIGITAL PADA PENGGUNAAN GADGET (Studi Deskriptif Penggunaan Gadget Pada Siswa SMK Broadcasting Bina Creative Medan Yang Berdampak Pada Pergeseran Nilai Kearifan Lokal)." JURNAL SIMBOLIKA: Research and Learning in Communication Study 4, no. 2 (2018): 173-87. https://doi.org/10.31289/simbollika.v4i2.1898.

Creswell, John W. Research design: pendekatan metode kualitatif, kuantitatif, dan campuran. Yogyakarta: Pustaka Pelajar, 2016.

Diniati, Ana, dan Jarkawi Jarkawi. "LAYANAN BIMBINGAN KELOMPOK DALAM MENGURANGI KECANDUAN ANAK YANG MENGGUNAKAN GADGET DI SMK NEGERI 1 PARINGIN." Jurnal Mahasiswa BK An-Nur: Berbeda, Bermakna, Mulia 3, no. 3 (2018): 1-4. http://dx.doi.org/10.31602/jmbkan.v3i3.1229.

DRC, ALK. Wawancara, 1 Januari 2020.

DRC, ATP, SGT, MGA. Wawancara, 1 Januari 2020.

Fitri, Ainil, Yulia Febrianita, dan Bayu Abdurrahman. "GAMBARAN PENGETAHUAN TENTANG PHUBBING AKIBAT KECANDUAN GADGET PADA GENERASI Z DI SMA NEGERI 9 KOTA PEKANBARU PROVINSI RIAU." Jurnal Keperawatan Abdurrab 3, no. 2 (2020): 46-52. https://doi.org/10.36341/jka.v3i2.1120.

Hidayat, Syarif. "Al-Qur'an Digital (Ragam, Permasalahan dan Masa Depan)." Mukaddimab: Jurnal Studi Islam 1, no. 1 (2018): 1-40. https://doi.org/10.14421/mjsi.11.1333.

Jalaluddin. Metode Telunjuk dalam Al-Qur'an. Jakarta: Grasindo, 2012.

Kasemin, H Kasiyanto. Agresi Perkembangan Teknologi Informasi. Prenada Media, 2016.

KIM, MAT, SGT. Wawancara, 1 Januari 2020.

KIM, SGT, MGA, JLS, SSH, ATP, ALK, DRC, MAT, DAS. Wawancara, 1 Januari 2020.

Kurniawati, Dian. "Pengaruh Penggunaan Gadget terhadap Prestasi Siswa." EDUKATIF: JURNAL ILMU PENDIDIKAN 2, no. 1 (2020): 78-84. https://doi.org/10.31004/edukatif.v2i1.78.

Kurniawati, Juliana, dan Siti Baroroh. "Literasi Media Digital Mahasiswa Universitas Muhammadiyah Bengkulu." Jurnal Komunikator 8, no. 2 (2016): 51-66.

MAD, KIM, JLS, SSH, Wawancara, 1 Januari 2020.

MGA dan JLS, SGT. Wawancara, 1 Januari 2020.

Miles, Matthew B, dan A Michael Huberman. Analisis Data Kualitatif. Terjemahan Tjetjep Rohendi Robidi. Jakarta: Penerbit Universitas Indonesia, 1992.

Nasrullah, Rulli. "Teori dan Riset Media Siber (Cybermedia): Edisi Pertama." Jakarta: Kencana Media Group, 2014.

Noormiyanto, Faiz. "Pengaruh Intensitas Anak Mengakses Gadget Dan Tingkat Kontrol Orangtua Anak Terhadap Interaksi Sosial Anak SD Kelas Tinggi Di SD 1 Pasuruhan 
Kidul Kudus Jawa Tengah." Elementary School 5, no. 1 (2018): 138-48. https://doi.org/10.31316/elementary\%20schoo.v5i1.607.

Rozalia, Maya Ferdiana. "Hubungan intensitas pemanfaatan gadget dengan prestasi belajar siswa kelas V sekolah dasar." Jurnal Pemikiran dan Pengembangan Sekolah Dasar (JP2SD) 5, no. 2 (2017): 722-31. https://doi.org/10.22219/jp2sd.v5i2.4821.

Sukmadinata, Nana Syaodih. Metode penelitian pendidikan. Bandung: Remaja Rosdakarya, 2005.

Wahbah, Maktabah. Pengantar Studi Ilmu Al-Qur'an. Jakarta: Pustaka Al-Kausar, 2005.

Widayani, Sri, dan Kamsih Astuti. "Pembentukan Karakter Melalui Pola Asuh Demokratis Untuk Mencegah Kecanduan Gadget Remaja Di Era Revolusi Industri 4.0.” Psycho Idea 18, no. 1 (2020): 74-81. https://doi.org/10.30595/psychoidea.v18i1.6234. 